\title{
VARIED CONCEPTS OF NATIONALISM IN RABINDRANATH TAGORE'S SELECTED WORKS
}

\section{Alpa Pragnesh Jani}

\section{$\underline{\text { Abstract }}$}

The present study is an attempt to analyze the various concepts of nationalism in Noble laureate Rabindranath Tagore's selected works. A detailed study of Rabindranath Tagore's works reveal that he has expressed himself in the different areas of literature but the main objective behind all those works, is to value Indian culture and to understand the extensive concept of nationalism. Tagore's ultimate object was to inspire the people about their rights of freedom and instigate the seed for peace of motherland. He was a man of true talent and his involvement in rising and growing nationalism in India is significant. The researcher has chosen specific collection of Tagore to narrate features of nationalism. The following are the books:

\section{Gora}

\section{Gitanjali}

At the end of the paper, the researcher has mentioned few specific features of Tagore as a nationalist.

Key Words: Loyalty towards a nation, Oneness, Nostalgia, Nationalism, Dedication 
जननीजन्मभूमिश्चस्वर्गादपिगरीयसीi.e. mother and motherland are superior to heaven. This concept conveys us that people should have owed their first and last duty as equal to motherland. One may find from the history of the world that large group of people were living together. They share languages, custom, culture and tradition. Many conflicts like revolutions, wars, mutinies took place throughout the history of universe. Innumerable instances inspire many people to get their own identity and own nation. One may call this spirit as 'nationalism'. Nationalism is a broad concept which plays a pivotal role to create the history of any country. The search of nation can direct person to the core of nationalism. One may specify that nation is an image of history, culture, tradition and political movement. The nation gives citizenship as equal to nationality and nationality can help to develop the feeling of nationalism. The feeling of oneness, pride on one's nation, loyalty, dedication and devotion is generally known as nationalism.

Literature is the mediator which gives ample of example for rise of nationalism in the world. The European's arrival became the main reason for the birth of nationalism in India. The European started to rule our nation in the year 1498. In the year 1526, Babar entered India and set the Mughal Empire. The Europeans established factories and the Portuguese, the Dutch and the British got inspiration because of the profitable trade. The British established east India Company in 1600. It was the first attempt by the British people to rule our nation. Though, there were some good aspects of the British people as they speeded awareness about the grip of blind faith, caste discrimination, evil customs, exploitation of women, superstations etc. But as we know that every coin has two sides: positive and negative. If we look to negative side, one may find helplessness, poverty injustice, slavery, exploitation etc. These aspects became the reasons for emergence of nationalism in India. The mutiny of 1857 was the first attempt to kick out the British people from India. This revolt was failure not because 
the British were stronger than us. Certainty because of our mistake that we had lack of coordination, leadership and dedication for motherland but this mutiny provided inspirations to the freedom movement in India. The construction of the India National Congress was also a turning point in the political movement in India. The period between 1885 to 1905 was most remarkable grown. There were two kinds of national leaders who were concentrating on political rights, economic and social development and even they wanted to eradicate social unjust, discrimination based on caste etc. The period between 1885 to 1905 is known as the period of "Moderates." The style of moderates was different to reject the British policies. But the few youth people found that the moderates could not perform anything with their ideas and demanded for action. These people were called "extremists". DadabhaiNavoji, Gopal Krishna Gokhle, Madan Mohan Malaviya, Surendranath Banerjee and many others were prominent moderate leaders. Bal Gangathar TilakGhosh, Lala Laipatrai, Rabindranath Tagore were extremist leaders. The main objective of leaders was to gain freedom for India the motherland. Secondly, they wanted to generate the feeling of nationalism amongst India to preserve own culture, heritage, custom, tradition and ancestral values. The leaders urged people by their deeds to consider India as a mother not as to piece of land.

People of India were carving for independence for a long time. In order to be free from the further of the time British rules they fought on different fronts with different ideologies. In may find the contribution of many young, energetic nationalist leaders fighting for India freedom in different parts of India. Among all those, the researcher is quite impressed by Rabindranath's peculiar contribution. Contribution of Rabindranath Tagore in the Struggle for independence through their national movement has inspired the researcher to do detailed probing in it. Even today views are relevant. 
The researcher has chosen specific collection of Tagore to narrate features of nationalism. The following are the books:

\section{Gora}

\section{Gitanjali}

\section{Brief life history of author:}

Long bearded, ingenious, handsome, dressed in nonwestern clothes Rabindranath Tagore was a noble laureate poet, writer, reformer, philosopher, nationalist musician, emissary of India culture and above all a great humanitarian. A detail study of Rabindranath Tagore's works reveal though he has expressed himself in the different areas of literature but the main objective behind all those works, is to value Indian culture and to understand the extensive concept of nationalism. Tagore's ultimate object was to inspire the people about their rights of freedom and peace of motherland. He was a man of true talent and his involvement in rising and growing nationalism in India is significant.

During the freedom movement of India, many people sacrificed their lives for motherland. Rabindranath is one of them. He was born on May 7, 1861 to Debendranath Tagore and Sharda Devi at Joransanko in West Bengal. He belonged to talented and scholarly family. Therefore, talent and intelligence was in his blood. Rabindranath Tagore completed his schooling from St. Xavier School. At the age of 17, he was sent to London by his father to acquire the Indian Civil Service education. But he did not complete education and returned to India.

Rabindranath Tagore has gifted National Anthems for two countries: India and Bangladesh. During the days of Indian freedom movement, several poets and writers of India produced ample of creative works for inspiring nationalism in India among the 
people. Among all the luminaries, Rabindranath Tagore was an India writer who contributed enormously to the nation. Rabindranath Tagore's literary works Gora and Gitanjali had some special objectives regarding the various concepts of nationalism. Rabindranath Tagore had proud of India and her unique heritage but he was also aware of India's faults.

Rabindranath Tagore's poem "Where the mind is without fear" from 'Gitanjali' in which he prays to God for equality and the atmosphere of freedom among the people of country. He desires in the poem that the world should not be broken up into pieces by the narrow credence like caste discrimination, inequality, injustice and many other social evils. He prays God to awake his people of country into heaven of freedom. He explains that freedom provides honor and self respect of nation as well as of individual. These thoughts reverberate in 'Gitanjali',

Where the mind is without fear and the head is held high;

Where the knowledge is free;

Where the world has not been broken up into fragments by narrow domestic walls;

Where the words come out from the depth of truth;

Where the tireless striving stretches its arms towards perfection;

Where the clear streams of reason have not lost its way into the dressy doesn't sand of dead habit;

Where the mind is led forward by thee into ever - widening thought and action - into that heaven of freedom, my country 
Let my country awake.

Rabindranath Tagore's 'Gora' is also the masterpiece which was written immediately after the first major rise in Bengal against the Swadeshi movement in 1908. He narrated all the major characters like Gora, Binoy, PareshBabu, Suchitra and Anadamoyi to represent his objectives. Gora originally, Gourmohan-is the central and pivotal character in the novel among all characters. Gora was drawn as the mouthpiece of Rabindranath Tagore in the entire novel. The main plot of the novel is concerned with Gora's attitude, beliefs and conceptions as a social human being, respect for motherhood, love, humanity, caste discrimination, women - emancipation, ideas for nation and nationalism, friendship, Social inequality, religion and spirituality were narrated as reflection of Tagore's thoughts in novel.

Gora is a fair faced man in the novel. People used to call him as a 'Snow man'. He was neither Bengali nor Indian. He was son of an Irish father and an English mother. He was brought up by Anandamoyi and Krishna Dayal when his mother died. Gora was a typical orthodox person. It seems clearly when he refused to learn Vedas from the pandits who were coming to Krishna Dayal's home. Even Gora rejected a cup of tea served by a lady servant lachmi. Yet one cannot deny Gora's noble ideas and feelings for country India and Hinduism. Through Gora, Rabindranath Tagore raised many contemporary social problems, social evils related to Hinduism and Brahmanism in the novel. Nationalism is the key aspect of this novel.

Characters like Pannubabu and Baroda Sundor are fond of the English style living and they considered the British rule as the assent God. 
One the other side, people like Mohim and Krishna Dayal had respect for English officials. Therefore, one cannot deny that the novelist was impressed by the western liberal attitude.

Rabindranath Tagore considers India not as a piece of land but as a Motherland and living image. Tagore portrayed the character of Suchitra as an epitome of Indian ethos of womanhood. It becomes clear in the speech of Gora, "It is a women who ought to be called the motherland - she it is who is seated on the hundred pedalled lotus, in the innermost abode of India's heart we are servitors."

Rabindranath's intensive love for nation comes in forefront when Gora speaks,

We must refuse to allow our country to stand at the bar of a foreign court and be judged according to a foreign low. Our ideas of shame or glory must not depend on minute comparisons at every step with a foreign standard. We must not feel apologetic about the country of our birth - whether it be about its tradition faith, or its scriptures - neither to other nor even to ourselves. We must save our country and ourselves from insult by manfully bearing the burdens of our motherland with all our strength and all our pride.(Gora 31-32)

Tagore creatively narrated in the illuminative speech of Gora the importance of uniformity to develop Nationalism. It echo as follows,

But I can never bear to see you laugh at the devotion of people of my country. You are regration the people of your country as fools and idolaters but I want to call them all and say: No, are not fools and idolaters; You are wise and you are true worshippers. By showing this reverence. I want to awaken the soul of country to the realization that there is greatness in our religious principle and depth in our devotion. I 
have bad an almost burning desire that I shall be able to see my country, Standing by your side and looking at her with one united vision for my India, ad a man , I can only work and if necessary die, but who except you, can light the lamp of welcome to her? If you cannot stand aloof the service of India can never be beautiful.(Gora 439)

One may find ideas of nation and nationalism from entire novel with the debate between Hinduism and English customs. It gives evidence when Gora broke out with his views,

What you say about evil customers. You have merely learnt off by heart from English boals - you know nothing at all about the matter at firs hand. When you are able to condemn all the evil customs of the English with a much honest indignation, you will have a right to talk. (Gora 61)

Gora expresses his feelings for India during the conversation with Binoy. He conveys,

I may miss my task, I may sink and down but that part of a great denting is always there. That is my India in its fullness full of wealth, full of knowledge, full of righteousness. Do you mean to say that such India is no where? Is there nothing but this falsehood on every side!(Gora 23)

Rabindranath Tagore believes that there is a special path leading to God for India. Gora tells to Suchitra in powerful voice,

Please don't think me to be a bigoted person, least of all one of those who have suddenly turned orthodox, - my words are not meant in their sense. 
My mind is in an ecstasy with the deep and grand duty which I have discover running though all of India's various manifestations and her manifold strivings, and this prevents me from shrinking to stand in the dust with the protest and most ignorant of my country man. This message of India some may understand some may not - that makes no difference in my feelings that I am one with all India, That all her people are mine, and I have no doubt that though all of them the sprite of India is secretly but constantly working. (Gora 143)

The core theme of nation and nationalism comes in more visible picture when Suchitra asked Gora, "Do you belong to any party?" Gora replied,

I am a Hindu! A Hindu belongs to no party. The Hindus are nation, and such a vast nation that their nationality cannot be limited within the scope of any definition. Just as ocean is not the same as its wave so Hindu are not the same as sects.(Gora 413)

Rabindranath Tagore found inequality among races and animosity for each other. Hence, he wanted the people to realize about their unity. A nation cannot be built only on ideal people but on the basis of peoples' harmony among each other. He tried to bring out the fusion of the East and West in the novel. Nevertheless, India has unique traditions and culture yet he was in search of national identity of an individual in the entire novel. Orthodox Gora, at the end attains true human nature. At the end he tells to Anandamoyi," 
Mother, You are my mother. The mother whom I have been wandering about in search of was all the time sitting in my room at home. You have no caste, You make no destinations, and have no hatred - you are only the image of our welfare! It is you who are India.(Gora Epilogue)

The novel Gora tells about pre - independence era yet the theme of the novel is pertinent to the present scenario. He narrated in this book that India in country where people are bound with different races, cultures, and religions.

From above mentioned drafts, the researcher had filtered few following features of nationalism in Rabindranath Tagore :

1. Prophet of Indian culture

2. Spiritual Enlightenment

3. Social equilibrium

4. Reciprocal relationship

5. Civilized nation

6. Devotion and loyalty

7. Motherland- Embodiment of mother 


\title{
$\underline{\text { References }}$
}

Das Gupta, Uma. Rabindranath Tagore: A Biography. New Delhi: Oxford University Press, 2004.Print.

Srinivasa, Iyengar. K. R. Indian Writing in English. New Delhi: Sterling Publication, 1965. Print.

Tagore, Rabindranath. Gitanjali. Embassay, 2011. Print.

Tagore,Rabindranath.Gora .India:RupaPublication,2002.Print.

\author{
Alpa Pragnesh Jani, Ph. D \\ Head \& Assistant professor \\ HVHP institute of Post Graduate Studies and Research \\ Sarva Vidyalaya Campus-kadi \\ KSV Unversity, Gandhinagar - 382 015, Gujarat, India. \\ Email: alparaval1820@yahoo.com
}

